https://helda.helsinki.fi

\title{
American Legal Realism and Anthropology
}

\section{Tuori, Kaius}

2017

Tuori , K 2017 , ' American Legal Realism and Anthropology ' , Law and Social Inquiry , vol. 42 , no. 3 , pp. 804-829 . https://doi.org/10.1111/lsi.12230

http://hdl.handle.net/10138/298256

https://doi.org/10.1111/lsi.12230

acceptedVersion

Downloaded from Helda, University of Helsinki institutional repository.

This is an electronic reprint of the original article.

This reprint may differ from the original in pagination and typographic detail.

Please cite the original version. 


\section{American Legal Realism and Anthropology}

Kaius Tuori

Post-print version, published in

Law \& Social Inquiry

Volume 42, Issue 3, 804-829, Summer 2017

Biographical statement.

Dr. Kaius Tuori is currently an Academy of Finland Research Fellow at the Network for European Studies of the University of Helsinki. This article is part of a larger research project on the history of legal primitivism (Tuori 2014). He would like to thank Bill Nelson, Dan Hulsebosch, Lauren Benton, Sally Merry, Toni Malminen and the anonymous reviewers for their comments and help. He gratefully acknowledges funding from the Academy of Finland, the University of Helsinki, New York University Hauser Research Scholar Program, the ASLA-Fulbright program, the Kone Foundation, the Osk.

Huttunen Foundation, and the European Research Council (FoundLaw project, grant number 313100). 


\begin{abstract}
The purpose of this article is to analyze the interdisciplinary co-operation and interaction between American legal realists and anthropologists during the interwar period. Using scholarly publications and manuscripts as its sources, it argues that despite the lack of recognition in earlier studies, there were transfers of important methodological and substantive influences that were crucial to the creation of legal anthropology as it is known today, as well as the whole field of law and society studies. Writers of the era like Karl N. Llewellyn, E. Adamson Hoebel, Felix S. Cohen, Franz Boas and Bronislaw Malinowski utilized interdisciplinary influences to criticize scholarly formalism as well as social and political conservatism, seeking to replace conceptual structures with scientific facts gained from studies.
\end{abstract}




\section{INTRODUCTION}

In the US, the prioritization of empirical inquiry over formal legal analysis was first argued by legal realists ${ }^{1}$ mainly in the first part of the twentieth century. As a part of the general drive towards the use of social science in legal discourse, legal realism sought to utilize anthropology, its approaches, data and methodology, to argue that the contemporary understanding of law was fundamentally flawed in many ways (Fisher, Horwitz, and Reed 1993, xi-xv). The movement coincided with the progressivism of the New Deal and beyond, and shared its goals of prioritizing social issues and development over the strict formal interpretation of rights such as the liberty of contract. ${ }^{2}$ Once the realist movement was sidelined and became a target of attack, ${ }^{3}$ this early interdisciplinary co-operation was nearly forgotten. As interest in the American legal realist scholarship has undergone a resurgence ${ }^{4}$ during recent decades that has again embraced anthropology (Merry 2006), it is high time to revisit this instance of mutual interest between legal realists and anthropologists in the interwar period.

Beyond the figure of Karl Llewellyn, ${ }^{5}$ the fact that realists were engaged in the study of legal anthropology or indigenous law has not gained recognition. In fact, in his book American Legal Realism and Empirical Social Science, John Schlegel does not even mention anthropology in the index, let alone take it up as a topic. Llewellyn's work with E. Adamson Hoebel on the Cheyenne tends to be the only example that is mentioned in the discussions on the interests of legal realists in anthropology (Schlegel 1995; Nader 2002, 8799). In studies such as Laura Kalman's Legal Realism at Yale, their book, The Cheyenne Way, is mentioned as the exception that confirms sweeping statements to the contrary, such as " $[\mathrm{t}]$ he realists did not find anthropology relevant", and "anthropology proved unhelpful". Kalman presents Llewellyn's and Hoebel's study as a curious sideshow without wider significance, its irrelevance proven with the oft-mentioned quote from Jerome Frank that Llewellyn would have spent his time better by studying the law-ways of the Tammany Hall braves, not Cheyenne Indians (Kalman 1986, 18). ${ }^{6}$

To counter these assessments, this article explores the mutual interest of American legal realists and anthropologists in the 1930s and 1940s, both through their theoretical formulations and their interest in indigenous legal traditions. Based on publications of the era and archival sources, it seeks to dispel the idea that what took place was simply a curious coincidence. I argue that the unusual convergence of legal realism and functionalist anthropology was founded on the shared goal of replacing hypothetical or metaphysical constructs with sound observations on reality. For functionalist anthropologists, this meant discarding the evolutionary sequences and biased accounts of the "primitives" by armchair anthropologists and replacing them with an understanding of the indigenous culture based on long-term participant observation. To legal realists, the aim was a similar scientific revolution by which fruitless, abstract conceptual analysis would be cast aside by empirical knowledge of the living law. What the article seeks to elaborate is the many 
forms that these connections took; the multiple ways of transmission and usage between legal realists and anthropologists. My purpose is not to prove that scholars like Schlegel or Kalman were wrong, but rather to demonstrate that what took place was a wider phenomenon than has thus far been recognized. ${ }^{7}$ Leading legal realists and anthropologists were involved in this process, which had an impact in both legal realism and legal anthropology. I am tracing evidence for this impact in convergences, transmissions, quotations and transfers of influences in both legal and anthropological scholarship, the way that theories and concepts crossed disciplinary boundaries.

I approach this issue by examining three points of convergence between the interests of legal realists and anthropologists. The first is the fascination many realists showed toward the possibilities offered by the social sciences and especially anthropology as a tool for social, moral and political criticism. Through the writings of the anthropologists Franz Boas and Bronislaw Malinowski as well as the legal realists Jerome Frank and Felix S. Cohen, I explore this criticism of logical and moral certainty, manifested in both social radicalism and cultural relativism. The second example is the transformation of legal anthropology, seen in the work of Malinowski, Karl N. Llewellyn and E. Adamson Hoebel, who replaced formalistic legal primitivism with functionalistic case analysis. The most famous interdisciplinary co-operation between anthropologists and realists that occurred at this time, the Cheyenne Way by Llewellyn and Hoebel, opened up new areas of research and co-operation. I present a new critical reading of the background and presuppositions of the book, as well as the vital contribution that it made. The third convergence of interests is that of the contested role of anthropology in administration and applied anthropology, when realists and anthropologists debated the role of science and scientific information in the application of the Indian New Deal. One of the most famous realists, Felix S. Cohen, was central to the advancement of the Indian New Deal, a comprehensive reform policy of the Indian tribes in which anthropologists were heavily involved. While both realists and anthropologists were part of the same progressive movement, what becomes painfully obvious in all of these examples is their lack of undeveloped understanding of the colonial context and its implications.

\section{THE FASCINATION AND FEAR OF RELATIVISM: LEGAL REALISTS DISCOVER ANTHROPOLOGY}

An integral part of the legal realist agenda was to connect law with social reality; the use of anthropology was a component in that enterprise. In his book That Noble Dream, Peter Novick links the simultaneous rise of legal realism and anthropology as signs of the general resurgence of empiricism in science. After the First World War, anthropology gained new visibility with ideas such as cultural relativism, the conviction that interpretations were dependent on the cultural background of their makers, permeating intellectual debate. Legal realism as an antiformalistic movement contested the claim that 
the judicial process was a logical combination of facts and rules to reach a rational conclusion. Like anthropologists, they claimed that the prejudices and backgrounds of the judges had an impact in the way they interpreted the case (Novick 1988, 143-149; Rabban 2013 , 474) ${ }^{8}$ Tracing the influence of issues like cultural relativism is a difficult task, as it was not only an important part of the self-understanding of both legal realism and functionalist anthropology, but also a defining feature of the post-War intellectual atmosphere. What I will argue is that this was an important part of the shared sense of purpose between realism and anthropology, and that methodological and theoretical influences were mainly sought from anthropology because of the fame of scholars like Boas and Malinowski, who served as the models of a stereotypical rational observer.

The iconoclastic attack of realists against classical legal thought was inspired by new developments in society at large and the conviction that current legal theory was unable to cope with them. This belief was strengthened by the new discoveries made by other disciplines that eroded the basis of formal conceptualism in science..$^{9}$ Echoing the antiformalistic criticism by Rudolf von Jhering in the German debate against conceptual jurisprudence (Herget and Wallace 1987), ${ }^{10}$ realists attacked Cristopher C. Langdell as a conservative arch-conceptualist who saw law as a closed system of logic. As a consequence of this attack on Langdell's reputation is still mostly defined by the caricature that realists made of him. ${ }^{11}$ While old rulebased theories understood law as a system of norms under which facts were subsumed, what united realists was the tendency to view law as behavior in a social setting, not a set of rules. By and large, realists subscribed to the famous example of Holmes, that "The life of the law has not been logic; it has been experience. The law embodies the story of a nation's development...it cannot be dealt with as if it contained the axioms and corollaries of a book of mathematics" (Holmes 2004, 1). ${ }^{12}$ Thus when Cohen wrote about Sapir's anthropological ideas on the illogical, emotional nature of language and its implications, stating that "Law is not a science but a practical activity, and myths may impress the imagination and memory where more exact discourse would leave minds cold" (Cohen 1935, 812), the point was that with the use of obscure and poetic language, it is possible to not talk about what the law is about, using it as a means of avoidance.

Some realists believed that jurists are, or should be, social engineers who would apply the scientific method to the social world in the form of public policy. This victory of reality over the normative was to be facilitated by the exact knowledge that social sciences like economics, psychology, sociology, and anthropology could now provide (Robinson 1934, 236, 264265). The realist's unlimited optimism and belief in science was criticized by Max Lerner, among others, who professed his skepticism when "people working on the study of societies begin arming themselves with scalpels, slide-rules and test-tubes" (Lerner 1938, 687). 
Anthropology, like psychology, political theory, and radical economic policy, was just one of the exciting new developments in social science that inspired jurists (Cohen 1935). Scholars like Franz Boas had contradicted evolutionary dogma and the belief in the inherent superiority of the white race in the process. In the late nineteenth century, anthropologists would subscribe to grand theories of unilinear cultural development that led from the lowest of savages such as Australian aboriginals towards the pinnacle of civilization, Western society. ${ }^{13}$ What Boas demonstrated in his famous works, such as the 1911 The Mind of Primitive Man, the beliefs that the "primitive man" is inherently prone to violence, superstition, irrational thinking and magic are false. Instead, these are social traits based on different circumstances. ${ }^{14}$ Boas claimed that "the mental processes of man are the same everywhere, regardless of race and culture, and regardless of the apparent absurdity of beliefs and customs" (Boas 1927, 1-2). However, one of the unanswered issues is that why these ideas made no apparent impact on realists. Despite their fascination with social radicalism, the connection between race, racism and the unity of man and the implications it could have had was not made.

Anthropologist Bronislaw Malinowski was a household name that was synonymous with anthropology for many legal realists in the same way that Laski meant political theory or Maitland legal history (Lerner 1934). Malinowski, one of the founders of social anthropology, had been teaching in the US intermittently since the late 1920s, teaching legal anthropology at Yale and visiting the New School, Harvard and a number of other institutions. Though Franz Boas was the undisputed star of the anthropological scene in the US, Malinowski's appeal to jurists was founded both on his attention to legal matters as well as his functionalistic methodology, which appealed to legal realists (Fenster 2003, 1086-1087).

Malinowski's writings presented him as a stereotypical heroic explorer, an intrepid anthropologist living among the natives (Firth 1960; Stocking 1996, 233-297; Young 2004). He was a student of Westermarck and Seligman at the London School of Economics and had conducted extensive fieldwork in Papua and the Trobriand Islands during the First World War. In his writings, he elevated fieldwork to a central part of his scientific image, creating what some observers have even described as a near mythical intrepid explorer character..$^{15}$ In the European context, this followed the trend towards indirect rule in colonial administration, which included commissioning anthropologists to explore the legal traditions of tribes in the colonies for the use of administrators (Malinowski 1926; Nader 2002, 71-87; Rouland 1994, 21-40; O’Barr 2002; Asad 1973; Bamett 1956).

The reason why Malinowski became such a central figure in the convergence of law and anthropology was that he wrote a brief but influential book titled Crime and Custom in Savage Society in which he argued for a new kind of legal anthropology to replace the antiquated studies of primitive law. Far from being a set of isolated curiosities and strange customs, law is actually a pervasive feature of indigenous life: 
Law and order pervade the tribal usages of primitive races, they govern the humdrum course of daily existence, as well as the leading acts of public life, whether these be quaint and sensational or important and venerable (Malinowski 1926, 2).

What Malinowski argued for was a study conducted through scientific participant observation instead of second-hand accounts, a study of ethnographic analysis instead of hypothetical theories of primitive promiscuity or primitive communism, or the ideas of the primitive man as without initiative and a slave to tribal custom (Malinowski 1926, 2-4). Like realists, Malinowski was critical of formalistic legal scholarship and its hypothetical constructs. As his view of culture was holistic, he was against the strict separation between law and other norms. ${ }^{16}$ What Malinowski sought to uncover by the application of participant observation was the underlying social mechanisms that found their outer expressions in things like law or magic. His main claim was that social interaction operated through mechanisms of reciprocity that defined all social, economic and political interaction. The role of legal and religious norms was to give form to these mechanisms, but they were mere garnishing and should not obscure the function that the mechanisms have in human interaction. The interest in the underlying functions beyond the obvious (hence, functionalism) was one of the uniting factors of the new type of anthropology (Stocking 1992, 38-40).

Like legal realists, Malinowski was fascinated by the potential of psychoanalysis as a way of providing explanations of the irrational, but he remained critical of Freudian theories. The reason was probably that Freud's theories used the old theories of totems, primitive mentalities and other antiquated anthropological ideas that Malinowski had rejected (Malinowski 1924; Malinowski 1927a, ix and passim; Malinowski 1927b; Stocking 1986, 13-49; Freud 1961).

Malinowski's importance in the new legal anthropology was stressed by legal realist Huntington Cairns ${ }^{17}$ in his 1931 essay on law and anthropology. After the nineteenth century antecedents of Maine, Morgan, Kohler, and Post had become outdated and their version of primitive law and its sterile conceptions ceased to interest either anthropologists or lawyers, Cairns argued that a new beginning had been made by Malinowski and Robert Lowie, a student of Boas (Lowie 1928)..$^{18}$ The renewed interest in interdisciplinary co-operation was eased by the fact that both law and anthropology shared a functional approach, for which Malinowski was mainly responsible on the anthropological side. A comparison with psychology was made even by Cairns, who noted how interdisciplinary attempts in the social sciences often resulted in shallow generalizations and fruitless applications. Because law and anthropology share so much common ground, a synthesis between the two would be valuable: "Today law and anthropology are in their program one" (Cairns 1931, 32-35). However, he identified three main fields where anthropology could be of value to jurists: the nature of law, legal history and law in action. On the first issue, the implications for Cairns were 
mostly about the culturally relative nature of the concepts of law, while for the historical part, legal anthropology would be invaluable for the understanding of early law and society. For the last part, the law in action, Cairns referred to applied anthropology and colonial administration, mentioning strangely enough Lord Lugard's book The Dual Mandate in British Tropical Africa, an apology for enlightened colonialism (Cairns 1931, 35-53). For both realists and functionalist anthropologists, colonialism was quite evidently beyond their radar. For all the talk about observing facts, the subjugation of indigenous peoples and its consequences was all but invisible in their works (Porter 2005). ${ }^{19}$

Felix S. Cohen was equally fascinated by the implications of the new type of anthropology and the functional approach to the study of the institutions of social organization and law through their functions. Cohen's main references were likewise Boas, Malinowski and Lowie. For Cohen, anthropology was one of the areas in which one could find tools for a new functional approach to law that would lay bare its social, cultural and economic context. His main interest was in deconstructing the mythological foundations of modern law, the muddy conglomeration of assumptions and bias that underlay classical legal theory. Thus, in his view, the implications of anthropology were mainly in legal theory (Cohen 1935, 831-842). ${ }^{20}$ However, functionalism was a method common to both law and anthropology:

[The] functional approach is a new intellectual invention which will solve all the problems of law (or of anthropology, economics, or any other science), we may turn to the significant question: "What are the new directions which the functional method will give to our scientific research?" (Cohen 1935, 830)

While Cairns and Cohen were generally positive about the impact of anthropology on the realm of law, William Seagle disagreed. A legal historian with a pugnacious personality, Seagle wrote an article in the American Anthropologist on how Malinowski and other anthropologists continuously misunderstood law. While Malinowski argued that law is just one of the manifestations of the mechanisms of reciprocity alongside custom and religion, Seagle sought to correct him by demonstrating the extraordinariness of law. Law is, for Seagle, the product of an organized force that is used to correct abnormalities in social relations. Custom is by no means interchangeable with law, being something categorically different, an automatic function: "The state is an alien and oppressive force. Its courts, as they develop, destroy the intimacy and naturalness of customary behavior patterns" (Seagle 1937, 285). Seagle's view on legal anthropology was strongly bound to the tradition of primitive law. As in his later writings, Seagle subscribed to the Weberian idea of the development of law as a rationalization process by which things like primitive communism and blood revenge were replaced by ownership and the state monopoly of violence. What made his attack on Malinowski so vehement was possibly that Malinowski was undermining the fundamentals of this conception by destroying notions 
like primitive communism by rejecting the inherent superiority of the categories of Western law. ${ }^{21}$

Columbia became the center for studies in law and anthropology in the 1930s in part because there were a number of people interested in interdisciplinary work both in law and anthropology. Franz Boas, the founder of cultural relativism and his students such as Ruth Benedict and Margared Mead were at the anthropology department, while Lowie had left Columbia for Berkeley in 1921. Boas, who published a book called Anthropology and Modern Life in 1928, was no stranger to the idea that anthropology could have an interest in the study of the modern world (Boas 1928). The faculty of law was a leader in legal realism with a lively interest in the cultural study of law, including Llewellyn, A. Arthur Schiller, who had replaced Hessel E. Yntema in the field of Roman and comparative law, and Julius Goebel Jr., who engaged in the study of the legal culture of colonial America (Goebel 1931). There was also an active interest in cross-disciplinary co-operation between law and anthropology, as a seminar in primitive law was organized in 19341935 with Llewellyn and Schiller participating from the law school and Boas, Benedict and Hoebel representing faculty from the anthropology department. ${ }^{22}$

This flourishing scene has been neglected in part because many influential legal realists had left Columbia, declaring it an intellectual wasteland. It would be fairer to say that legal realism changed shape. The group of self-described legal realists that left Columbia Law Faculty claimed that their departure meant the end of legal realism in Columbia, except for Llewellyn, who was left behind (Schlegel 1995, 6). ${ }^{23}$ The impact was not as dramatic, as can be demonstrated by simply looking at the law school curriculum and the works published by the faculty. Nevertheless, the departure of five realists was not without significance (Columbia University Bulletin of Information, School of Law 1929-1930, 1929; Tomlins 2000, 934).

Columbia realists were not alone in their interest in the findings of anthropologists. At Yale, Jerome Frank and Thurman Arnold were equally fascinated with anthropology. In Frank's case, anthropological data was used to support claims that ultimately rested on psychological foundations. He discussed the uncertainty and indeterminacy of law and science with links to quantum physicist Werner Heisenberg's principle of indeterminacy, ${ }^{24}$ psychologists of the Freudian school, and the anthropological Sapir-Whorf hypothesis (Frank 1949, 326-327). ${ }^{25}$ Frank's basic dilemma was the conflict between the popular expectation that law be certain and unequivocal and the uncertain character of the law as presented by jurists themselves, as demonstrated by the writings of legal realists and their predecessors. This longing for certainty is for Frank the basic myth of law, which has its foundation in the universal need for fatherly authority figures. To prove the universality of this myth, Frank turns to Malinowski's anthropological studies, which claimed that in all patriarchal cultures the father as the head of the family takes the role of a strict judge, being the ultimate authority and arbitrator. Malinowski writes that family relationships form the pattern upon 
which all relationships are based which, in his Freudian psychological reading, Frank interprets as one more reason why father-substitutes are being sought from authority figures such as the judge (Frank 1949, 6-12, 15-16). Frank's conception of modern legal magic is seen as a logical development from the use of magic in primitive societies, as ways of ritually dealing with and attempting to manipulate things beyond one's control (Frank 1969, 42-44). ${ }^{26}$

Thurman Arnold had a similar approach to anthropology as Frank, using anthropological data to provide supposed general truths of culture and anthropological vocabulary to underline the novelty of his approach. Despite the use of words like folklore, symbol, and ritual, anthropology was to Arnold mostly a dilettante fad and he seems to not have engaged with it seriously (Arnold 1935; Arnold 1937a; Fenster 2003, 1084-1086). ${ }^{27}$ A contemporary observer described Arnold's "anthropology of contemporary attitudes" having revolutionary potential as an exposition of the ritualistic nature of social activity, its function being mostly theatrical. ${ }^{28}$

For the scholars of legal realism, the social sciences were a continuing source of inspiration and fascination. The findings of anthropology, sociology, psychology, and economics gave them intellectual ammunition for the fight against legal formalism; the tendency of law to support the status quo, to live in the realm of concepts and to disregard social realities.

It is probable that cultural relativism was the most important import that realists wanted to take from anthropology. What the realists wanted to show through anthropology was that much of what had been taken for granted in American society was actually a cultural phenomenon. As cultural radicals, many realists relished the subversive implications of books like Coming of Age in Samoa (1928) by Boas's student, Margaret Mead. Sexual liberation and the reversal of traditional mores were just some of the aspects of this radicalism. The social, political and moral upheaval that had begun with the First World War and the Russian Revolution of 1917 continued throughout the interwar period. Modernism, cultural radicalism and labor unrest, and underlying them the specter of socialism, threatened traditional social norms. Many of the radical scholars identified with the margins of society like the bohemianism and counterculture of Bloomsbury and Greenwich. Both Malinowski and his students envisioned themselves as radical and avantgarde, questioning the established conventions of society, morality, religion, family, romantic love, political structures and psychology (Wetzsteon 2002; Nicholson 2005; Stocking 1996, 294-295). However, relativism was of course a general phenomenon not restricted to anthropology, since the comparative approach of anthropology made it appealing for uncovering universal truths. In many cases, the involvement of realists in anthropology did not go beyond a superficial use of fashionable terms and the invocation of comparisons.

Both realism and functionalism were modernist scholarly movements that questioned notions of rationalism and subjectivity. The new functionalist anthropological scholarship sought to dispel notions of the hierarchical structures of civilization and evolution. For the traditional Western minds 
attempting to understand the expanding world, the idea of an evolutionary sequence of the development of rationality and morality was a practical tool by which all cultures and societies could be ranked. Functionalists criticized the social scientific arguments of their predecessors which combined racism, political expediency, observations of culture and brain size, and social Darwinism, linking race and civilization with preconceived notions such as that only white men were completely civilized (Morgan 1877 (reprint 1964), 39; Kuklick 1984, 63; Stocking 2001, 10-20). Many legal realists harbored similar ideals of questioning established political, legal and social conventions and were drawn to the model of the interventionist administrative state of the New Deal, where policy aims of development were justified at times by scientific studies.

The rejection of fixed rules and hierarchies was perhaps the clearest link between realism and anthropology. They both sought to demonstrate how law could be found in the interactions, conflicts and cooperation between people. Though formalistic scholarship on both modern and primitive law underlined the fundamental limitation of rationality for Western law, what realists and functionalist anthropologists attempted to do was to redefine what was meant by rational and to deny any exclusive claim to rationality by any race, ethnic group or some other denominator. What this fundamental unity of man also meant was that, as in psychology, anthropological data could be used to gain a deeper understanding of humanity.

\section{BEYOND LEGAL PRIMITIVISM: ANTHROPOLOGISTS DISCOVER REALISM}

While realists and anthropologists shared many theoretical presumptions about the human condition and development, these agreements were on the presuppositions of scholarship, not about how scholarly investigation should be carried out. The exchange of influences as a direct application of methodologies from other fields remained a challenge, a phenomenon that has often been ascribed to the insularity of legal thought. Despite these obstacles, there were many co-operative efforts that had significant impacts, such as the most famous instance of co-operation between legal realism and anthropology, Llewellyn and Hoebel's book, The Cheyenne Way (1941).

The Cheyenne Way has had a mixed reputation, to put it mildly. For example, Wilf has argued that even though the book was a significant step in the process, it was not founded on functionalist anthropology, but the earlier tradition of legal primitivism (Wilf 2009). Legal primitivism was an offshoot of evolutionary social anthropology based on the relic or fossil hypothesis, which claimed that there were preserved remnants of the earliest human condition in certain cultures that had had little contact with the outside world. While social evolution had progressed, these remnants were left behind like the skeletons of dinosaurs. What I will be arguing here is that even though the book was rooted in contemporary ideas like legal primitivism, it managed to 
produce something entirely novel and very influential, but this impact was not what was expected. That a variation of the case method, the observation of conflict resolution, would become the favored approach to the study of legal anthropology was the unintended consequence of this project.

The book in its final form was groundbreaking in that it provided legal anthropology with a whole new direction in the study of conflicts instead of laws strictly understood. The trouble case method as proposed by Llewellyn and Hoebel was thought to be problematic, but the general direction was approved and, with the help of Max Gluckman, the teachings of legal realism spread to legal anthropology through the Manchester School and the teachings of Sally Falk Moore. ${ }^{29}$ What the book showed was how one could escape the vestiges of conceptualism and cultural hierarchies that earlier legal anthropology had relied upon.

As with any ground-breaking work, it is easy to forget where Llewellyn and Hoebel had started out., The main issue they were initially facing was whether indigenous people like the Cheyenne had law at all (Conley and O'Barr 2004, 202). Llewellyn and Hoebel's book was a selfconscious effort to break from the normative mold established by earlier anthropologists and currently called rule-based legal anthropology.

The book collected and presented the laws of the "primitive" culture as in a codification..$^{30}$ When no clear rules were to be found, it was determined at times that the primitive people simply had no laws. For example, Hoebel mentions how, a Comanche informant was asked in an earlier study, "What kind of law did you have?" He answered simply "We didn't have any law in the old days." With that, the matter was closed (Hoebel 1964, 736). What Llewellyn and Hoebel wanted to do was to observe the law as it manifested itself in the cases among the Cheyenne. The preoccupation about whether or not there might be law in some societies was quite widespread. For example, Radcliffe-Brown argued that for law to exist, there should be a minimum definition, just as in religion. Thus, Evans-Pritchard began his fieldwork on the Nuer with the presumption that there was no law to be found (Vincent 1990, 170-171). For Llewellyn, the influences underlying the work were his interest in the scholarship on legal primitivism and the role that it played in the works of Weber, Sumner and Keller. Twining writes that the most immediate impulse for the project was Llewellyn's reading of Malinowski's Crime and Custom and his disappointment in the complete lack of coverage of adjudication (Twining 1973, 153).

Hoebel recalls that his first contact with Llewellyn in 1933 was a note reading: "I understand you are interested in American Indian Law. So am I. Could I talk to you?" (Hoebel 1964, 735) Llewellyn, by then a law professor at Columbia Law School, and Hoebel, a graduate student in anthropology at Columbia, were introduced by Franz Boas, who was looking for someone to help Hoebel to finish his doctoral dissertation on the Comanche. After a year, Hoebel had completed the study and suggested to Llewellyn that studying the Cheyenne might prove to be productive. The project was approved and co- 
signed by Boas and funded by Council for Research in the Social Sciences at Columbia University. ${ }^{31}$

Llewellyn and Boas shared German pasts. Boas had emigrated to the US after completing his studies in Berlin, while Llewellyn had studied in a German Gymnasium and even fought in the German Army during the First World War (Twining 1973, 87-99; Conley and O'Barr 2004, 182-183). Llewellyn was a character larger than life, a charismatic and idiosyncratic teacher as well as a crusading lawyer who gained notoriety in his participation in the so-called Sacco-Vanzetti case in defense of the accused anarchists. He became one of the leading figures of the realist movement after his famous debate with Pound, wrote numerous brilliant yet eccentric works and was central to the drafting of the Uniform Commercial Code (Twining 1973; Ansaldi 1992-1993, 705-777). In short, Llewellyn was no regular law professor.

Llewellyn had numerous acquaintances among anthropologists at Columbia. He was in regular contact both with Boas and Julius Lips of the anthropology department and he also supervised Richardson's study on the Kiowa. In fact, Llewellyn was co-applicant in several projects involving Boas and Lips. ${ }^{32}$

The Cheyenne Way comprises fifty cases and the accompanying analysis. Through the analysis of these cases, Llewellyn and Hoebel illustrate Cheyenne legal thought and the way that Cheyenne society seemingly operated without any apparatus of law, written laws, police, judges, prisons or courts. In order to grasp the original and true tradition of the Cheyenne, the analysis was based on historical cases collected from recollections of informants in 1935-6 of events that took place in the mid-nineteenth century.

The original plan of the book was quite different. The first outlines were of a comparative study that would have put much more emphasis on general theories. The initial plans for the study emphasized how primitive law was tied to modern law. The stated questions of the study were: "1) What can modern society, and modern law, contribute to study of law in primitive culture? 2) What can primitive law contribute to the understanding of modern culture?"33 The aim was to produce a general theory of primitive law by combining ethnographic material gleaned from previous studies with a theoretical framework, much in the same vein as primitive law scholarship had sought to present a unified total theory. ${ }^{34}$

During the years that followed the original plans and the fieldwork, the orientation of the project changed. The result was a book concentrating purely on Cheyenne law. Why this happened is not clear, but what is evident is how much Llewellyn and Hoebel were carried away with their material, raving about its "juristic beauty," declaring that "one finds no ready parallel to this legal genius of the Cheyennes among primitives" (Llewellyn and Hoebel 1941, ix, 313). Beyond the casual racism of that comment there is a fundamental shift. What this implied was that there was a culture of highly 
developed legal argument and conflict resolution that existed without any reference to written law.

The book was concerned with conflict management, the analysis of how conflicts were channeled and settled in real cases. The methodology that was used they defined as "realistic sociology" (Llewellyn and Hoebel 1941, viii), the study of the "law-ways" of primitive peoples. Although they claimed adherence to the social sciences, the methodological outlook resembled the American case-law method more, but with significant differences. The peculiar terminology of "law-ways" and "law-stuff" were possibly taken from Sumner's influential study on folkways (Llewellyn and Hoebel 1941, viii-ix; Nader 2002, 88), ${ }^{35}$ but the analysis of cases was strictly analytical descriptions of conflicts and their resolution with the various social, political, religious and moral elements involved.

The fifty cases in the book took place roughly between 1820 and 1880 . Because the interviews were carried out in 1935 and 1936, the material consisted mostly of second-hand recollections by elderly informants. However, the intention of the study was not purely anthropological or historical, even though it was commonly interpreted as such. In fact, the cases provide an exposition of the Cheyenne legal culture and the traditional ways of conflict resolution. The anthropological reviewers of the study criticized it as an anthropological fieldwork study, a deeply flawed collection of second-hand material. This interpretation persists even in the most recent evaluations, which deride it as poor anthropology (Llewellyn and Hoebel 1941, viii-ix; Conley and O'Barr 2004, 189; Moore 1999, 102). ${ }^{36}$ What this narrow anthropological criticism misses is the stated intention of Llewellyn and Hoebel, which was to collect the important cases of the Cheyenne legal culture as they are remembered and how they form the basis of conflict resolution. Because the Cheyenne were an oral culture, remembering the past was an important way of controlling the future; in this case, how the remembrance of cases past formed the framework for dealing with future cases.

While Boas had spent a year in his first fieldwork expedition in the Arctic, and Malinowski several years in the Trobriands, the fieldwork done by Llewellyn and Hoebel was fairly limited in scope and concentrated on interviews with informants. Llewellyn stayed on the reservation only for ten days, while Hoebel spent two summers conducting the interviews. However, they openly stated their aim of approaching the material as a cultural recollection, presenting it "against the moving time-perspective of the culture and the individual life." What this meant was that they saw it more akin to the collection of folklore, as parts of culture, than the observation of actual behavior (Llewellyn and Hoebel 1941, ix; Conley and O'Barr 2004; 185-89; Mehrotra 2001, 757). Legal culture and the remembered past had a distinctly normative character, the memory of how issues were resolved functioning partly as a guide, partly as a shared conviction about the law and its content.

The problem with The Cheyenne Way was that it was judged at the outset as an anthropological study with faulty methodology. Even Malinowski 
criticized its lack of fieldwork credentials (Malinowski 1942, 1).

Consequently, it is quite ironic that the primary importance of the book was methodological. Even though there were no laws, police, or courts, it demonstrated that the Cheyenne had law and one could study that law through the resolution of cases. While earlier legal anthropology had been concentrated on the search for fixed rules or laws, the realist approach of law in action enabled them to circumvent the whole issue. For example, Malinowski's review of the Cheyenne Way pays homage to its roots in realist thought: "Where there are no books, we have only law in action" (Malinowski 1942, 8; Conley and O'Barr 2004, 202). Perhaps more importantly, the use of cases allowed scholars to address the idea about custom as a shared and uncontested monolith and to show how discussions about tradition were part of the legal experience. Of course, when succeeding scholars like Gluckman and Bohannan utilized the case method, they would do it within the framework of participant observation by observing the cases being argued in court (Twining 1973, 163, 166-167, 433). ${ }^{37}$

The contrast between the study of law in books and law in action was, of course, moot in legal anthropology in cases where there were no books but the fundamental distinction was more profound. If the basic idea of legal conceptualism is making a legal construction of reality, in realism one produces a construction of law from reality. Realists and anthropologists both maintained that one learns the rules of human behavior through the observation of reality. However, the main object of Llewellyn and Hoebel was not actual behavior but rather the legal customs of the Cheyenne. Thus instead of legal primitivism, as Wilf maintains, The Cheyenne Way could be seen as a sharing the roots of anthropology in an even older tradition, that of German Romanticism and its concentration on culture and legal custom as a shared conviction of the people. This living custom would be then defined in the resolution of conflicts, not some abstract rules or laws. ${ }^{38}$

The greatest deficiency of The Cheyenne Way was not its reliance on second-hand accounts of early cases that were recorded through an interpreter. It was, as Nader has pointed out, its conviction that the tradition would remain unchanged and unified. For Llewellyn and Hoebel, the Cheyenne were a way of proving a point about how much the process of resolving disputes was separated from the text of the law. In the meantime, what they did not see was that the traditional Cheyenne culture had changed as a result of the forced migrations, wars, loss of traditional livelihoods and disease. Their Cheyenne was a romantic vision of the past, coincidentally much like the constructions of the scholars of German romanticism (Nader 2002, 94-95). However, this criticism is only partially accurate. In The Cheyenne Way, there are both sections where the Cheyenne conflict resolution is idealized and compared positively with modern America, a type of exotic primitivism, but there are also sections where they discuss the impact of the vanishing buffalo and the military defeats of the Indian Wars. ${ }^{39}$ What remained of the Cheyenne was 
what was left of the culture after the US military pacification campaigns, forced resettlement and the general impact of colonialism on the defeated. ${ }^{40}$

After its publication, the work of Llewellyn and Hoebel gained recognition within the anthropological community, perhaps because its universal nature helped to overcome its shortcomings. Llewellyn started out with the traditional anthropological method of seeing the natives as living in a timeless and unchanging past. Even contemporary observers noted that the strength of the study was in its theoretical aspects. Malinowski wrote that "The greatest importance of the book consists in the theory of law in general and of primitive law in particular..." (Malinowski 1942, 1) He criticized them for both their fieldwork and a lack of knowledge of a lot of the relevant literature (Malinowski 1942, 2). Even the structuralist Claude Levi-Strauss said that the social, cultural, and economical context is missing in The Cheyenne Way (Levi-Strauss 1942, 157).

Llewellyn had developed the idea of studying law through dispute resolution even in the modern context and thus the case method that he applied to the Cheyenne material was something he had already been developing. Despite its name, Llewellyn's theory had little in common with the case method originally developed by Langdell. Llewellyn's student Sally Falk Moore maintained that in The Cheyenne Way, a subtle legal analysis was being applied to a crude, fragmentary assemblage of historical evidence (Llewellyn 1951, 108; Moore 1999, 102). However, Moore is also quick to remind the reader that during the 1940s most of the literature available was of the "Tribes and Traditions" genre that assumed that there were rules and people adhered by them. The Cheyenne Way made the radical claim that people actually worked the rules. There were many similarities as well, because the "Tribes and Traditions" ethnographers also hoped to reconstruct the native way of life in its pre-contact form, and to place it in an evolutionary framework (Moore 2004, 102-3).

Was Llewellyn interested in the Cheyenne themselves, or were they merely an exotic other that would be used for argument in a discussion that was essentially about formalism and realism in law, an alter ego of modernism? (Wilf 2009, 487-490, 505-506) This impression is strong when Llewellyn and Hoebel write about the Western legal tradition and the instances of legal genius that they admire, such as the Roman jurists. Through the Cheyenne example, Llewellyn is writing about the ideal lawyer and the ideal legal culture, which is centered in the case method. Just as he had written in the first outlines, Llewellyn wanted the book to speak to the modern American lawyer (Llewellyn and Hoebel 1941, 268, 308-309, 311-313).

Despite this difference in focus, it is equally evident that Malinowski, Llewellyn and Hoebel saw the fundamental sameness of their approaches. In his review, Malinowski considered Llewellyn and Hoebel to be functionalists. More recently, it has been stated that "Malinowski was a legal realist" (Vincent 1990,164). Whether or not that is factually true or an attempt to bundle him into the American debate, it is clear that the aims and methods of 
functionalist anthropology and legal realism were convergent in a productive way. The methodological input of legal realism proved to be long-lasting in legal anthropology. Although the implementation of the trouble case method in The Cheyenne Way was less than ideal, it came to have far-reaching consequences since the processualist approach and the case method it outlined became the standard method of legal anthropology, at least in the Englishspeaking world (Twining 1973, 160, 166-167, 433).

\section{APPLICATION, SCIENCE AND COLONIALISM: APPLIED ANTHROPOLOGY AND ITS USES}

While the purpose of Llewellyn and Hoebel was to examine Indian law-ways in a historical setting without the practicalities of the present, academic anthropology was just one of the disciplines in which realist legal scholars encountered indigenous law; applied anthropology in the context of the Indian New Deal was another area where legal realism and anthropology met in the US. Even here, the lasting consequences of this meeting were not the intended one, the improvement of the Indian administration, but rather the use of anthropological data in the legal challenges to the federal government. This example is somewhat different from the two previous ones, because the focus is on the practical application of anthropological data in administration and legal cases rather than the development of scholarly doctrine. Because a central part of the realist idea was the use of social scientific knowledge to aid in decision-making, it is very relevant for the question of influence between realism and anthropology.

A new type of colonial governance was being formulated at the same time as a response to social unrest and criticism of the colonial enterprise at the turn of the century. In contrast to the exploitative colonialism that preceded it, the new colonial administrations sought to improve the colonial societies and in particular their economies. For that purpose, colonial administrations needed exact scientific information about the indigenous communities, their lives, laws and culture. Institutions like the RhodesLivingstone Institute thus commissioned anthropological scholars to draft reports and surveys of the natives and their laws during the interwar period. These projects employed some of the leading scholars of the time and produced many important anthropological works. ${ }^{41}$ Both anthropologists and lawyers were recruited by the new colonial administrations (Vincent 1990, 156-157). This self-image of the enlightened character of the interwar colonial administrations has been heavily criticized by post-colonial scholarship, which has pointed out the gaping discrepancies between the declared good intentions of the colonial administrators and the exploitative realities on the ground. ${ }^{42}$ What the story of applied anthropology and the Indian administration reveals is the blindness of both American and European progressives to the destructive colonial underpinnings of the situation.

Many leading anthropologists like Malinowski in fact saw anthropology as a beneficial force in the colonial administration, improving 
the government of "savage races" by providing more accurate information and thus making it less destructive for the indigenous peoples (Malinowski 1926, xi). Why this was relevant to the meeting of legal realism and anthropology was that one of the numerous realists who were recruited to the Federal administration during the New Deal was Felix S. Cohen. The author of some of the most recognized texts of the realist movement, Cohen worked for much of his career as a solicitor for the Department of the Interior, where he was actively involved in American Indian affairs under the progressive Commissioner for Indian Affairs, John Collier. Cohen was the crucial legal architect behind the Indian Reorganization Act of 1934, which sought to strengthen Indian self-governance and land tenure (Cohen 1954, 345-350; Tsuk Mitchell 2007).

The self-governance of Indian tribes was quite limited in the typical way of colonial administrations, by which limited autonomy within tribal entities was entrusted with applying the simplified version of the laws of the colonial state, much like in the British and French colonies. Within Indian territories, a tribal court system was initially founded on the informal administrative practice of the Bureau of Indian Affairs (BIA), which was then formalized in 1883 as Courts of Indian Offences., These courts operated at least nominally by their own sets of rules with abbreviated civil and criminal codes. Such courts did not exist when tribes already had their own tribal governments and courts or when it was not considered necessary. Only after the Indian Reorganization Act of 1934 were most tribes allowed to determine what laws were applied to them (Pommersheim 1995, 61-65). ${ }^{43}$ However, even the progressive agenda that dominated the federal government policies was based on development, not the preservation of tribal culture.

To help with the reorganization of Indian tribes, BIA sent a questionnaire to anthropologists about the customs, traditions, and the organization of various groups in 1934 (Tsuk Mitchell 2007, 80). The decision to have anthropologists involved was based on a seminar organized the previous May by ethnologists and Indian service officials in which the virtues of anthropological training to British and Dutch colonial officers were explored.$^{44}$ Also present at the meeting was R. R. Radcliffe-Brown, a recent hiring at the University of Chicago. In addition to Malinowski, RadcliffeBrown was one of the most influential anthropological scholars of the generation. Although he is now known mostly through his later structuralist works, at the time Malinowski saw him as a functionalist (Stocking 1996, 362366). ${ }^{45}$

The incorporation of anthropologists into the BIA that began shortly thereafter led to the institution of an applied anthropology unit under $\mathrm{H}$. Skudder Mekeel. The separate applied anthropology detachment was disbanded in 1938, but anthropologists continued to serve the BIA in various roles even later (Tsuk Mitchell 2007, 108). However, conflicts began to emerge within this co-operation. 
During his work with the Bureau of Indian Affairs, Cohen wrote a paper based on his experience working with anthropologists in which he did not hide the evident antagonism between anthropologists and the BIA: "The word anthropology is a red flag to the regular Indian Service administrator. To him it generally connotes a breed of people that look upon Indians as museum exhibits to be measured and cataloged rather than as human beings ..." (Cohen 1936-1937, 171) According to Cohen, many anthropologists thought that Indian Service officials were simply " "disturbing factors' in the search for anthropological truth," not part of an historical process of acculturation. At the time of writing, this division was showing signs of weakening as both anthropologists and administration officials have changed their views of their respective missions. Not all anthropologists thought that "anthropology can only be studied in the purity of the past" (Cohen 1936-1937, 171). Cohen's paper was a direct attack on the tradition of anthropology that Llewellyn and Hoebel were pursuing at the same time in Montana.

Because of the rather harsh choice of words, getting the paper published was difficult. Considering the fact that in the original manuscripts sent to the first journals Cohen spoke of the mutual feeling of contempt between anthropologists and Indian service officials, who thought "that nothing useful or realistic can be expected from the anthropologists", it would not have been surprising that they would have found the paper offensive as well. ${ }^{46}$

Cohen's skepticism about the value of anthropology was a marked change from his earlier enthusiasm for its value as an ally in academic debates. It should be remembered equally that Cohen had himself studied anthropology at Harvard and earlier praised the discipline's capability for reform. Cohen claimed that the functional method in anthropology represented a break from both listing of peculiarities and the evolutionary approaches. As an example of the benefits of this new approach in the study of primitive law he lists the studies of Malinowski:

In anthropology, the functional method represents a movement away from two types of study: the naive reporting and classification of striking human peculiarities; and the more sophisticated attempt to trace the historical origin, evolution and diffusion of "complexes." Those who have embraced the functional approach (not all of whom have invoked the word "functional"), have been primarily concerned to trace the social consequences of diverse customs, beliefs, rituals, social arrangements, and patterns of human conduct. This approach has led to fertile fields that most earlier investigators missed (Cohen 1935, 831). Cohen's attack on the uselessness of traditional anthropology may best be understood in the context of legal realism, not simply the inherent conflict within the ideals of progressivism pervading the federal government and the willingness of some anthropologists to continue the study of Indians as the vanishing relics of a culture. What Cohen had hoped for was reliable and 
unbiased information based on scientific methods, information that could be useful for the formulation of policies.

Even here, the controversies led to an unexpected success in the use of anthropology in Indian affairs in providing fact-based research for litigation. Anthropological research could be used to demonstrate the existence of land rights by illustrating the customary system of land tenure and how these land rights had not been respected in the state legal system. The case U.S. v. Santa Fe RR. 314 U.S. 339 (1942), in which Cohen was actively involved in defending the rights of the Hualapai tribe, used anthropological studies to prove their occupation rights to good effect. According to Cohen, it demonstrated the relevance of anthropology to administration better than his 1937 article. ${ }^{47}$ It showed how anthropological research could be used to prove the existence of customary legal traditions and ownership rights to support claims, a very important precedent for the use of anthropologically demonstrated facts in legal proceedings. This early success story has since been followed by a global movement in which anthropological research has been utilized to counter the formalistic thinking that has been the foundation of state legal systems and their land registries in particular.

The transformation of Cohen's view on anthropology parallels his involvement in Indian affairs. If Cohen was less than enthusiastic about anthropology while writing the Ethical Systems, ${ }^{48}$ a few years later he demonstrates in Transcendental nonsense a similar interest in functional anthropology as the revealer of universal truths about human cultures, like his fellow legal realists (Cohen 1935, 831). At the BIA, Cohen's criticism of anthropology followed the role anthropology could have played in the administration of Indian affairs as a practical means of gathering information instead of a theoretical light to shine on Western society. ${ }^{49}$ Cohen's early advocacy of Indian rights was a political campaign for equality and pluralism, made more pressing with the impact of antisemitic propaganda and racism. Although in this campaign he made use of anthropology only as a tool, it was surprisingly similar in its aims to Franz Boas's efforts to utilize anthropology to disprove racism (Tsuk Mitchell 2007; Boas 1965, 126-127). However, the most important legacy of this development for the future is the use of anthropology to demonstrate indigenous land rights claims against colonial states.

\section{CONCLUSIONS}

Was Laura Kalman right after all about American legal realists and anthropology, that realists found anthropology irrelevant? On the surface it appears that there was little that jurists found to be of use in anthropology. That is, however, not the whole story. In fact, the convergence of legal realism and anthropology was an important episode in the development of contextual jurisprudence and brought new influences to bear on legal scholarship. For anthropology, the encounter was likewise productive, but in a different manner. In this article, I have outlined three instances in which anthropologists 
and legal realists met and co-operated. What is noteworthy and important for inquiries about the connections and interactions between law and social science is the central role of serendipity and unintended consequences in determining which of the myriad connections would prove to be important for the future of the disciplines.

The most prominent encounter was that around cultural relativism. Both legal realism and functionalistic anthropology were movements born out of cultural and political radicalism and both had an interest in questioning previous certainties on man, culture and society. Furthermore, they both sought to influence man, culture and society in an anticonservative fashion. Their main opponents they fashioned as representatives of that conservatism in science; in the case of realists, legal formalism and in the case of anthropology, legal primitivism. While they sought to demolish the rationalities of conservative thought in science, such an enterprise was not without a political agenda, because questioning the naturalness of private property, monogamous marriage or racial inequality had revolutionary potential.

In the case of academic legal anthropology, this encounter led to a methodological revolution. Its instigator was Llewellyn, a radical professor who used the Cheyenne as an example mainly for his own purposes. While his vision of the Cheyenne was a romantic one, his unintended consequence of the introduction of the case method had far-reaching consequences. Llewellyn would go down in history as one of the founding fathers of legal anthropology for three reasons. The Cheyenne Way was sufficiently universal and theoretical not to be tied to details that would become dated. Secondly, the book spoke to anthropologists and Hoebel kept talking about it to noted anthropologists, ensuring its survival. Third, it was a book written by a legal celebrity.

The implications of the convergence for applied anthropology are not as direct, as it involved both realists and anthropologists working within the federal administration or in legal cases to improve the lives of indigenous peoples. Their intention was to combine advocacy and scholarship by providing better information for the basis of either administrative policies or legal decisions. In much the same way as in the other two instances, their aim was to produce more accurate knowledge of reality using scientific methods.

In conclusion, the main reasons for the affinity between legal realism and anthropology stemmed from both their shared aims and the complementary nature of their strengths. First, anthropological scholarship could provide facts for making legal claims, contributing to the processes of indigenous agency. In case law, the Hualapai case brought anthropological data as a way to demonstrate claims contrary to the formalistic arguments of state authorities. Second, anthropological studies could function as a critical element in the analysis of law, especially the impact of law. Third, interactions between law and anthropology were able to stimulate the discourse in both fields, not to mention the exciting field of legal anthropology itself. 
The convergences of interest and exchanges of ideas between legal realism and anthropology that I have traced took different forms, many of them elusive influences and appropriations of concepts and theories from the other fields (hence the need to use terms like "affinity", "shared purpose" or "convergence"). While scholars like Schlegel and Kalman had seen little or no mutual influence between anthropology and legal realism, their interest lay in scholars who did not share the fascination for anthropology. What I hope to have demonstrated is how leading legal realists like Llewellyn, Cohen, Frank and Arnold were influenced by functionalist anthropology in different ways. By using archival research as well as references within their publications, I sought to demonstrate how these connections were not simply the result of superficial encounters (though those took place as well), but long-standing collaboration between scholars of different fields. Equally, my aim had been to show how these influences were carried both ways across the doctrinal boundaries and how legal anthropology was equally a beneficiary.

\section{REFERENCES}

Ansaldi, Michael. 1992-1993. The German Llewellyn. Brooklyn Law Review 58: 705-777.

Arnold, Thurman. 1935. The Symbols of Government. New York: Harcourt, Brace \& World.

----- 1937a. The Folklore or Capitalism. New Haven: Yale University Press.

1937b. The Jurisprudence of Edward S. Robinson. Yale Law Journal 46: 1282-1289.

Asad, Talal (ed.). 1973. Anthropology \& the colonial encounter. London: Ithaca Press.

Ayres, Clarence Edwin. 1933. Ethical Systems and Legal Ideals, Book Review. Yale Law Journal 43: 158-160.

Bamett, Homer Garner. 1956. Anthropology in Administration. Evanston: Row, Peterson and Co.

Bernstein, David E. 2012. Rehabilitating Lochner. Chicago: University of Chicago Press.

Boas, Franz. 1927. Primitive art. Oslo: H. Aschehoug \& Co. 1928. Anthropology and Modern Life. New York: W. W. Norton. 
1965 (reprint of the 1938 revised edition). The Mind of Primitive Man. New York: The Free Press.

Brown, Dee. 1970. Bury My Heart at Wounded Knee. New York: Holt, Rinehart and Winston.

Chanock, Martin. 1985. Law, Custom and Social Order. Cambridge:

Cambridge University Press.

Cohen, Felix S. 1935. Transcendental Nonsense and the Functional Approach. Columbia Law Review 35: 809-849. 1936-1937. Anthropology and the Problems of Indian Administration. The Southwestern Social Science Quarterly 18: 171-180.

----- 1945. Colonialism: A Realistic Approach. Ethics 55: 167-181.

Cohen, Lucy Krammer. 1954. Biography of Felix S. Cohen. Rutgers Law Review 9: 345-350.

Cole, Douglas. 1999. Franz Boas: The early years, 1858-1906. Vancouver: Douglas \& McIntyre.

Columbia University Bulletin of Information, School of Law 1929-1930. 1929. New York: Columbia University.

Conley, John M., and O'Barr, William M. 2004. A Classic in Spite of Itself: The Cheyenne Way and the Case Method in Legal Anthropology. Law and Social Inquiry 29: 179-216.

Cox, Oscar. 1931. Review of J. Frank, Law and the Modern Mind. Yale Law Journal 40: 670-673.

Dagan, Hanoch. 2013. Reconstructing American Legal Realism \& Rethinking Private Law Theory. New York and Oxford: Oxford University Press.

Deloria, Vine Jr. 1988. Custer died for your sins: An Indian manifesto. Norman: University of Oklahoma Press.

Fenster, Mark. 2003. The Symbols of Governance: Thurman Arnold and PostRealist Legal Theory. Buffalo Law Review 51: 1086-1087.

Firth, Raymond. 1960. Man and culture: An evaluation of the work of Bronislaw Malinowski. London: Routledge \& Kegan. 
Fisher, William W., Horwitz, Morton J., and Reed, Thomas A. 1993. Introduction. In American Legal Realism, ed. William W. Fisher, Morton J. Horwitz, and Thomas A. Reed, xi-xv. New York: Oxford University Press.

Frank, Jerome. 1949. Law and the Modern Mind. London: Stevens \& Sons.

----- 1969. Courts on Trial: Myth and Reality in American Justice. New York: Atheneum.

Freud, Sigmund. 1961. Civilization and Its Discontents. New York: W. W. Norton \& Company.

Geertz, Clifford. 1988. Works and Lives: The Anthropologist as Author. Stanford: Stanford University Press.

Gluckman, Max. 1972. The Ideas in Barotse Jurisprudence. Manchester: Manchester University Press.

Goebel, Julius Jr. 1931. King's Law and Local Custom in Seventeenth Century New England. Columbia Law Review 31: 416-448.

Haferkamp, Hans-Peter. 2004. Georg Friedrich Puchta und die 'Begriffsjurisprudenz'. Frankfurt: Klostermann.

Hartland, Edwin. 1924. Primitive Law. London: Methuen \& Co. Ltd.

Herget, James E., and Wallace, Stephen. 1987. German Free Law Movement as the Source of American Legal Realism. The Virginia Law Review 73: 399456.

Hoebel, Edward Adamson. 1963-1964. Karl Llewellyn: Anthropological Jurisprude. Rutgers Law Review 18: 735-744.

1964. The Law of Primitive Man. A Study in Comparative Legal Dynamics. Cambridge, Mass: Harvard University Press.

Holleman, J. F. 1994. Trouble-Cases and Trouble-less Cases in the Study of Customary Law and Legal Reform. In Folk law: Essays in the theory and practice of Lex non scripta, vol. 2, ed. Alison Renteln Dundes and Alan Dundes, 601-624. New York: Garland Publishing.

Holmes, Oliver Wendell. 2004. The Common Law. New Jersey: The Lawbook Exchange, Ltd. 
Horwitz, Morton J. 1992. The Transformation of American Law, 1870-1960:

The Crisis of Legal Orthodoxy. New York: Oxford University Press.

Hull, N. E. H. 1997. Roscoe Pound and Karl Llewellyn. Searching for an American Jurisprudence. Chicago: University of Chicago Press.

Kaberry, Phyllis. 2004. Women of the Grassfields. London: Routledge.

Kalman, Laura. 1986. Legal Realism at Yale 1927-1960. Chapel Hill: University of North Carolina Press.

Kantorowicz, Hermann. 1934. Some Rationalism about Realism. Yale Law Journal 43: 1240-1242.

Kuklick, Henrika. 1984. Tribal Exemplars: Images of Political Authority in British Anthropology, 1885-1945. In Functionalism Historicized: Essays on British Social Anthropology, ed. George W. Stocking, Jr, 59-82. Madison: University of Wisconsin Press.

Kuper, Adam. 1988. The invention of primitive society: Transformations of an illusion. London: Routledge.

Le Cour Grandmaison, Olivier. 2010. De l'indigénat. Anatomie d'un "monstre" juridique: Le droit colonial en Algérie et dans l'Empire français, Paris: Zones.

Leiter, Brian. 1997. Rethinking Legal Realism: Towards a Naturalized Jurisprudence. Texas Law Review 76: 267-315.

2007. Naturalizing Jurisprudence: Essays on American Legal Realism and Naturalism in Legal Philosophy. New York: Oxford University Press.

Lerner, Max. 1934. Book Review: Modern Theories of Law. Yale Law Journal 43: 855-856.

1938. The Shadow World of Thurman Arnold. Yale Law Journal 47: 687-703.

Levi-Strauss, Claude. 1942. Review: The Cheyenne Way, Conflict and Case Law in Primitive Jurisprudence. By K. N. Llewellyn and E. Adamson Hoebel. Journal of Legal and Political Sociology 1: 155-157.

Lips, Julius. 1947. Naskapi Law (Lake St. John and Lake Mistassini Bands): Law and Order in a Hunting Society. Transactions of the American Philological Society 37 (4): 379-492. 
Llewellyn, Karl. 1951. The Bramble Bush: On our law and its study. New York: Oceana.

Lowie, Robert. 1928. Incorporeal Property in Primitive Society. Yale Law Journal 37: 551-563.

Lugard, Frederick. 1965. The Dual Mandate in British Tropical Africa. London: Frank Cass.

Macaulay, Stewart. 2005. The New versus the Old Legal Realism: “Things Ain't What They Used to Be". Wisconsin Law Review 2: 365-403.

Malinowski, Bronislaw. 1942. Mutterrechtliche Familie und Ödipuskomplex. Berlin: Internationaler Psychoanalytischer Verlag.

----- 1926. Crime and Custom in Savage Society. London: Kegan Paul.

----- 1927a. Sex and Repression in Savage Society. London: Routledge \& Kegan.

1927b. The Father in Primitive Psychology. London: Kegan Paul, Trench, Trubner \& Co. Ltd.

------ 1936. 74. Primitive Law. Man 36: 55-56.

1942. A New Instrument for the Interpretation of Law - Especially

Primitive. A Review of The Cheyenne Way. Lawyers Guild Review 2: 1-12.

1972. Introduction. In Law and Order in Polynesia, ed. Ian Hogbin, xviilxxii. New York: Cooper Square Publishers, Inc.

----- 1989. A Diary in the Strict Sense of the Term. Stanford: Stanford University Press.

Mamdani, Mahmood. 1996. Citizen and Subject: Contemporary Africa and the Legacy of Late Colonialism. Princeton: Princeton University Press.

McMillen, Christian W. 2007. Making Indian Law: The Hualapai Land Case and the Birth of Ethnohistory. New Haven and London: Yale University Press.

Mehrotra, Ajay K. 2001. Law and the "Other": Karl N. Llewellyn, Cultural Anthropology, and the Legacy of The Cheyenne Way. Law and Social Inquiry 26: $741-775$. 
Merry, Sally Engle. 2006. New Legal Realism and the Ethnography of Transnational Law. Law and Social Inquiry 31: 975-995.

Moore, Sally Falk. 1978. Law as Process. London: Routledge. 1999. From Lawyer's Law into the Academic Zoo. Political and Legal Anthropology Review 22: 101-105.

Morgan, Lewis Henry. 1877 (reprint 1964). Ancient Society. Cambridge, Mass: Belknap Press of Harvard University Press.

Nader, Laura. 2002. The Life of the Law: Anthropological Projects. Berkeley: University of California Press.

Nicholson, Virginia. 2005. Among the Bohemians: Experiments in living 1900-1939. New York: Perennial.

Nourse, Victoria, and Shaffer, Gregory. 2009. Varieties of New Legal Realism: Can a New World Order Prompt a New Legal Theory? Cornell Law Review 95: 61-137.

Novick, Peter. 1988. That Noble Dream: The "Objectivity Question" and the American Historical Profession. Cambridge: Cambridge University Press.

O'Barr, William M. 2002. Back to the Trobriands: the Enduring Influence of Malinowski's Crime and Custom in Savage Society. Law and Social Inquiry 27: 847-871.

Papke, David Ray. 1999. How the Cheyenne Indians Wrote Article 2 of the Uniform Commercial Code. Buffalo Law Review 44: 1457-1485.

Parker, Kunal. 2003. The History of Experience: On the Historical Imagination of Oliver Wendell Holmes, Jr. Political and Legal Anthropology Review 26: 60-84.

Paul, Jeremy R. 2006. Felix Cohen's Brand of Legal Realism. Connecticut Law Review 38 (4): 593.

Pommersheim, Frank. 1995. Braid of Feathers: American Indian Law and Contemporary Tribal Life. Berkeley: University of California Press.

Porter, Robert Odawi. 2005. Sovereignty, Colonialism and the Indigenous Nations: A Reader. Durham: Carolina Academic Press. 
Pound, Roscoe. 1930-1931. The Call for a Realist Jurisprudence. Harvard Law Review 44: 697-711.

Rabban, David. 2013. Law's History: American Legal Thought and the Transatlantic Turn to History. New York: Cambridge University Press.

Radcliffe-Brown, A. R. 1935. Patrilineal and Matrilineal Succession. Iowa Law Review 20: 286-303.

Radin, Max. 1931. Legal Realism. Columbia Law Review 31: 824-828.

Richardson, Jane. 1940. Law and Status among the Kiowa Indians. New York: J. J. Augustin.

Robinson, Edward S. 1934. Law - an Unscientific Science. Yale Law Journal 44: 823-847.

Rohner, Ronald Preston, and Rohner, Evelyn C. 1969. Introduction: Franz Boas and the Development of North American Ethnology and Ethnography. In The ethnography of Franz Boas, ed. Franz Boas, Ronald Preston Rohner, and Hedy Parker, xiii-xxx. Chicago: University of Chicago Press.

Rouland, Norbert. 1994. Legal Anthropology (transl. P. G. Planel). Stanford: Stanford University Press.

Schapera, Isaac. 1994. A Handbook of Tswana Law and Custom. Compiled for the Bechuanaland Protectorate Administration. Münster-Hamburg: LIT Verlag.

Schlegel, John Henry. 1989. The Ten Thousand Dollar Question. Stanford Law Review 41: 435-467.

1995. American legal realism and empirical social science. Chapel Hill: University of North Carolina Press.

Schumaker, Lyn. 2001. Africanizing Anthropology: Fieldwork, Networks, and the Making of Cultural Knowledge in Central Africa. Durham: Duke University Press.

Seagle, William. 1937. Primitive Law and Professor Malinowski. American Anthropologist, New Series 39: 275-290.

1946. The History of Law. New York: Tudor Publishing Co. 
Snyder, Francis G. 1981. Anthropology, Dispute Process and Law: A Critical Introduction. British Journal of Law and Society 8: 141-180.

Speziale, Marzia. 1980. Langdell's Concept of Law as Science: The Beginnings of Anti-Formalism in American Legal Theory. Vermont Law Review 5: 1-37.

Stocking, George W. Jr. 1974. A Franz Boas Reader: The Shaping of American Anthropology, 1883-1911. Chicago: University of Chicago Press.

1983. Observers observed: Essays on ethnographic fieldwork. Madison: University of Wisconsin Press.

1986. Anthropology and the science of the irrational: Malinowski's Encounter with Freudian Psychoanalysis. In Malinowski, Rivers, Benedict and others: Essays on Culture and Personality, ed. George W. Stocking, Jr., 1349. Madison: University of Wisconsin Press.

1992. The Ethnographer's Magic and Other Essays in the History of Anthropology. Madison: University of Wisconsin Press.

----- 1996. After Tylor. British Social Anthropology, 1888-1951. London: Athlone.

2001. Delimiting Anthropology: Occasional Essays and Reflections. Madison: University of Wisconsin Press.

Tamanaha, Brian. 2009. Understanding Legal Realism. Texas Law Review 87 (4):731-785.

Tomlins, Christopher. 2000. Framing the Field of Law's Disciplinary Encounters: A Historical Narrative. Law and Society Review 34: 911-972.

Tsuk Mitchell, Dalia. 2007. Architect of Justice: Felix S. Cohen and the Founding of American Legal Pluralism. Ithaca: Cornell University Press.

Tuori, Kaius. 2014. Lawyers and Savages. London: Routledge.

Twining, William. 1973a. Karl Llewellyn and the Realist Movement. Norman: University of Oklahoma Press.

1973b. Law and Anthropology: A Case Study in Inter-Disciplinary Collaboration. Law and Society Review 7: 561-584. 
Vincent, Joan. 1990. Anthropology and Politics. Tucson: The University of Arizona Press.

Wetzsteon, Ross. 2002. Republic of dreams: Greenwich Village, the American Bohemia, 1910-1960. New York: Simon \& Schuster.

Whitman, James Q. 1987-1988. Commercial Law and the American Volk: A Note on Llewellyn's German Sources for the Uniform Commercial Code. Yale Law Review 97: 156-175.

1990. The Legacy of Roman Law in the German Romantic Era.

Princeton: Princeton University Press.

Wilf, Steven. 2009. The invention of legal primitivism. Theoretical Inquiries in Law 10: 451-476.

Yntema, Hessel. 1931. The Rational Basis of Legal Science. Columbia Law Review 31: 925-955.

${ }^{1}$ Definitions of realism by realists vary; see Pound 1930-1931, 697-711; Radin 1931, 824-828; Yntema 1931, 925-955; Kantorowicz 1934, 1240-1242. Horwitz 1992, 208-212 argues that legal realism is hard to define, as the movement had no clear leader or programmatic texts.

${ }^{2}$ This interpretation of progressive jurists fighting for equality, social justice and regulation over the strict interpretation of liberties such as that of the libertarian interpretation of the liberty of contract in Lochner has been challenged by Bernstein 2012, 4-5, who argues that progressives were liable to defend racism, segregation and sexism if they saw fit.

3 Leiter $(1997,267-315)$ cites the criticism of Hart contributing to the misunderstanding of realism and the CLS movement's embrace of realism in particular as a further cause for misreadings. 
${ }^{4}$ The interest in legal realism has taken many forms, including Leiter 2007; Tamanaha 2009, 731; Dagan 2013. This interest is not purely historical; see, for example, Nourse and Shaffer 2009.

5 The best biography is still Twining 1973a, but see also Whitman 1987-1988; Ansaldi 1992-1993; Hull 1997. On Llewellyn's interests in anthropology: Hoebel 1963-1964; Twining 1973b; Papke 1999; Mehrotra 2001; Conley and O’Barr 2004.

${ }^{6}$ See also Schlegel 1989. Schlegel's defining influence in the way that realism and social sciences is seen is apparent in studies like Macaulay 2005.

${ }^{7}$ The discrepancy is largely due to focus. Schlegel's book focuses mostly on Cook, Moore and Clark; Kalman on Yale realists. Both are interested in the impact of social science on law, not the other way around. I have explored the larger context of the shared past of legal and anthropological scholarship in Tuori 2014.

${ }^{8}$ Kalman (1986, 4-44) dubs the legal realists functionalists, whose greatest common denominator was their opposition to the reigning Langdellian formalism, or as Kalman calls it, conceptualism.

${ }^{9}$ Cox 1931, 672: "Because of the many changes which are going on about us in both our environment and viewpoints it is well for the legal profession to reexamine its thought processes. If the preoccupation with the workings of the mind does not result in creative paralysis, it is usually well justified. In literature André Gide and James Joyce have carried on a scathing investigation of the craft of fiction and have made original and vital contributions to their field; in music 
Stravinsky and Ravel have been preoccupied with the workings of the musical mind and have benefited by it; in art Monet, Picasso and Matisse have reexamined and reformulated the theories of painting; in medicine Drs. White and Crookshank have started many of the doctors thinking about their thinking; in psychology and philosophy the researches of Freud, Whitehead, Russell, Croce and Dewey have resulted in an unusual fecundity; in politics and history Professor Laswell has just contributed a memorable book based on a clear and exhaustive study of the best of the modern studies on psychology; and in law those judges and jurists, such as Holmes, Cardozo, Hand, Pound, Lehman, Hutcheson, Cook, Llewellyn, Green and Roscoe Pound, who have thought most about their thinking, have made the best contributions to law and jurisprudence." See also Fisher, Horwitz, and Reed 1993, xiii.

${ }^{10}$ Parker (2003) argues that Holmes derided Langdell and the formalists as "German" and forgot to mention his own roots in German jurisprudence.

11 Speziale (1980) attempted to salvage some of Langdell's reputation. For example, Cohen (1934) uses Jhering's jurisprudential satire to criticize conceptualism. Incidentally, the reputation of the German 19th century school of jurisprudence of concepts is still also defined by its critics; see Haferkamp 2004.

${ }^{12}$ See Rabban 2013, 227-234 on Holmes's discovery of history.

${ }^{13}$ On Boas, see Rohner and Rohner 1969, xiii-xvii; Kuper 1988, 125-151; Cole 1999, 2-4; Stocking 1974; Stocking 2001. 
14 "It has also been claimed that lack of control is exhibited by primitive man in his outbursts of passion occasioned by slight provocations. In this case also the difference in attitude of civilized man and of primitive man disappears if we give due weight to the social conditions under which the individual lives. We have ample proof that his passions are just as much controlled as ours, only in different directions" (Boas 1965, 126-127). See also Boas 1927, 3.

15 This heroic image was tarnished by the publication of his private diaries in 1967 as A Diary in the Strict Sense of the Term (Malinowski 1989). On the diaries, see Young 2004; Stocking 1983, 110-112; Geertz 1988, 73-101.

${ }^{16}$ Malinowski papers at London School of Economics (Malinowski/21), N. Lecture \& 9. Primitive Law (Oct 17, Dec 6, 1933); Malinowski/21, 18. Diamond.

${ }^{17}$ Even for the often unconventional career paths of legal realists, Cairns stands out. A legal philosopher, he was recruited to the federal administration and served for almost twenty years at the National Gallery of Art, getting to know artists and authors of his generation and writing many works on art, including The Limits of Art.

${ }^{18}$ On Malinowski's contribution to the development of legal anthropology, see Vincent 1990, 159-171.

19 Of course, Malinowski talks about the effects of colonialism on the indigenous culture, but rarely sees it as an issue. Cohen (1945) does discuss colonialism and the ills of European powers, but does not see the American Indian experience as part of the same phenomenon, unlike the current view. 
${ }^{20}$ For Cohen $(1935,830,834)$, functionalism was a method common to law and anthropology, as well as economics. The main applications of the functional method were theoretical, such as the definition of law, the nature of legal rules, the theory of legal decisions and the role of legal criticism.

${ }^{21}$ Seagle 1937, 288 on ownership and communism. See also Seagle 1946.

${ }^{22}$ A. Arthur Schiller Papers 1897-1977, MS\#1125 Rare Book \& Manuscript Library, Columbia University in the City of New York, box 31, African Law, file Lips, Seminar in Primitive law.

${ }^{23} \mathrm{He}$ also claims that Llewellyn never engaged in empirical research.

${ }^{24}$ Heisenberg demonstrated that in subatomic levels, the very act of observation influences the object.

${ }^{25}$ The anthropologists Edward Sapir and Benjamin Lee Whorf claimed, on the basis of observations of expressions such as the descriptions of the color of the ocean, that linguistic structures influence perception.

${ }^{26}$ Even here Frank uses Malinowski's definition of magic.

${ }_{27}$ Arnold $(1937 \mathrm{~b}, 1283,1286)$ uses the word anthropologist to describe an outside observer of culture.

${ }^{28}$ Lerner $(1938,688-689)$, of the revolutionary nature (p. 688): “They are the sappers and miners of a social order; dangerous men because they belong to the breed of anthropologists, and anthropologists are always more dangerous when they study their own culture than when they dose themselves with quinine and deck themselves out in mosquito netting to study a savage culture. If the anthropologists who study primitive tribes are the forerunners of missionaries 
and traders, those who turn to their own cultures are the forerunners of revolutionists."

${ }^{29}$ This transfer was neither straightforward nor traceable solely to Llewellyn; see, for example, the reminiscences of Gluckman 1972. On the crucial influence of legal realism on the new type of legal anthropology, see Moore 1978, 217, and Chanock 1985, 28: "This tendency was consolidated by the rise of the realist school of American jurisprudence, which found its way into anthropology through the publication of The Cheyenne Way."

${ }^{30}$ This development was summarized in Hartland 1924.

${ }^{31}$ Karl Llewellyn Papers, Special Collections Research Center, The University of Chicago Library, section I, folder 4: Chamberlain, Llewellyn, and Boas to Council for Research in the Social Sciences at Columbia University, March 1, 1935.

${ }^{32}$ Application for funds to be considered by the Council for Research in the Social Sciences at its meeting on Jan. 25, 1937, Re: Indian Law; MontagnaisNascopi; Julius Lips, Columbia University Archives, Council for Research in the Social Sciences 1922-1970 (1925-1968), UA\# 127, Series III: Projects, 1925-1968, box 11, folder 17: Project No. 103, - Negro Caribbean Culture, Franz Boas, 1935-1938; Richardson 1940, vi; Lips 1947, 379.

${ }^{33}$ Llewellyn, "L.I.P.C. outline,” Karl Llewellyn Papers, section I, folder 5.

${ }^{34}$ Karl Llewellyn Papers I.4, Llewellyn to the Council for Research in the Social Sciences at Columbia University, Nov. 18, 1935. 
35 The influence of Sumner shows that Llewellyn was not averse to accepting influence from conservative scholars.

${ }^{36}$ The most important contemporary critics were Levi-Strauss $(1942,157)$ and Malinowski $(1942,1)$.

37 The influence of Llewellyn and Hoebel is acknowledged even outside the circle of American and British anthropologists, Snyder (1981, 142-143), but see also Holleman (1994, 601-624). Considerably more negative: Conley and O’Barr 2004, 181-182, 207-213.

${ }^{38}$ See, for example, Whitman 1990.

${ }^{39}$ Compare, for example, Llewellyn and Hoebel 1941, 108-111 and 302-309.

${ }^{40}$ The story of the Cheyenne is crucial in Dee Brown's Bury My Heart at Wounded Knee (1970), for example.

${ }^{41}$ For example, Kaberry 2004; Schapera 1994. On the RLI, see Schumaker 2001.

${ }^{42}$ Compare, for instance, the depictions of old colonial hand Lugard 1965, and Mamdani 1996 or Le Cour Grandmaison 2010.

${ }^{43}$ For a different perspective on the legal and political development, see Deloria 1988.

${ }^{44}$ Felix S. Cohen Papers, Yale Collection of Western Americana, Beinecke Rare Book and Manuscript Library, series 1, file 10 Notes on discussion ethnologists and Indian service officials Sat, May 28, 1934 in Washington, D. C. Radcliffe-Brown was invited to demonstrate the anthropological training given to British Colonial officers. 
${ }^{45}$ Malinowski and Radcliffe-Brown began a very public and long lasting dispute around the same time; see Radcliffe-Brown 1935, 286-303; Malinowski 1936, 55-56; Malinowski 1972, xvii-lxxii.

${ }^{46}$ The article was rejected by a number of leading anthropology journals; see Felix S. Cohen Papers, series 1, file 7, 'another draft' of 'Notes on the place of Anthropology', letter of Leslie Spier to Cohen, Jan 16, 1937. On the other hand, Robert Lowie gave him a favorable review, Felix S. Cohen Papers, series 1, file 7, 1 Lowie to Cohen, May 27, 1936.

${ }^{47}$ Quoted in Tsuk Mitchell 2007, 200. On this case, see also McMillen 2007. ${ }^{48}$ Ayres 1933, 160: "Doctor Cohen is almost never contemptuous except when he is slamming the door on anthropology."

${ }^{49}$ Paul $(2006,599)$ claims that Cohen's legacy for law and anthropology is in the appreciation of the way local cultures interpret rules through social realities. 